\title{
Determination of Resistance Mutation in Chronic Hepatitis $B$ Patients Using Antiviral Drugs at Our Hospital
}

\author{
Hastanemizde Antiviral Ilaç Kullanan Kronik Hepatit B Hastalarında Direnç \\ Mutasyonlarının Saptanması
}

\author{
Begüm SARAN, Uğur TÜZÜNER, Bahadır FEYZIOĞLU, Mehmet ÖZDEMIR, Mahmut BAYKAN
}

Necmettin Erbakan University Meram Faculty of Medicine, Department of Microbiology, Konya, Turkey

\begin{abstract}
Objective: In this study, it is aimed to determine the mutations responsible for drug resistance in patients with chronic hepatitis $B$ virus (HBV) infection received/receiving antiviral treatment at our hospital and to examine the patients in terms of the treatment applied and their HBV-DNA levels.

Materials and Methods: One hundred and thirty-one samples taken from patients diagnosed with chronic hepatitis B infection between January 2010 and January 2015 at Necmettin Erbakan University Meram Faculty of Medicine Hospital were studied with reverse hybridization principle-based INNO-LiPA HBV DR v2 method and the results were evaluated retrospectively.

Results: Mutation was determined in 12 samples (9.1\%). While tyrosine, methionine, aspartate, aspartate (YMDD) pattern change causing lamuvidine resistance was determined in 10 samples, 7 of them were observed to be M204l tyrosine, isoleucine, aspartate, aspartate (YIDD) and 4 were M204V tyrosine, valine, aspartate, aspartate (YVDD). Multiple mutations were determined in six samples (M204V+M204I+L180I，YVDD+L180M+V/G173L，YIDD+L180M, YIDD+L80V in one each and YIDD+L80I, YVDD+L180M in two each) and single mutation was determined in 3 samples (YIDD in two samples and N236T and L80V in one each). Control HBV-DNA levels were evaluated in patients with resistance gene after 6-12 months and a decrease in DNA level was observed in 11 of 12 patients. Conclusion: Since a limited number of mutations can be examined via LiPA method, it is concluded that different mutation patterns causing drug resistance cannot be determined and it will be beneficial to use an additional method such as sequencing that enables to determine these genes. Additionally, as a result of treatment failure due to drug resistance, if the treatment will be continued with a novel drug that is not used before, it is considered that the possibility of the presence of mutations causing a resistance against this antiviral should not be neglected.

Keywords: Hepatitis B, drug resistance, mutation
\end{abstract}

$0 ̈ Z$

Amaç: Bu çalışmada, hastanemizde antiviral terapi almış/alan kronik hepatit B virüs (HBV) enfeksiyonu olan hastalarda ilaç direncinden sorumlu mutasyonların belirlenmesi, hastaların verilen tedavi ve HBV-DNA düzeyleri yönünden incelenmesi amaçlandı.

Gereç ve Yöntemler: Necmettin Erbakan Üniversitesi Meram Tıp Fakültesi Hastanesi'nde Ocak 2010 - Ocak 2015 tarihleri arasında kronik hepatit B enfeksiyonu tanısı ile takip edilen hastalardan alınan ve hastanemiz mikrobiyoloji laboratuvarına gönderilen 131 örnek ters hibridizasyon temeline dayalı INNO-LiPA HBV DR v2 yöntemi ile çalışıldı ve sonuçlar retrospektif olarak incelendi.

Bulgular: Yüz otuz bir örneğin 12'sinde $(\% 9,1)$ mutasyon saptanmıştır. On örnekte lamuvidin direncine neden olan tirozin, metiyonin, aspartat, aspartat (YMDD) motif değişikliği belirlenirken bunların 7'si M204I tirozin, izolösin, aspartat, aspartat (YIDD), 4'ü M204V tirozin, valin, aspartat, aspartat (YVDD) şeklinde izlenmiştir. Altı örnekte çoklu mutasyon (birer örnekte M204V+M204I+L180I, YVDD+L180M+V/G173L， YIDD+L180M， YIDD+L80V; ikişer örnekte YIDD+L80I, YVDD+L180M), 3 örnekte tekli mutasyon (iki örnekte YIDD, birer örnekte N236T ve L80V) saptanmıştır. Direnç geni tespit edilen hastaların 6-12 ay sonra yapılan kontrol HBV-DNA düzeyleri incelenmiş ve 12 hastanın 11'inde DNA düzeyinde düşüş izlenmiştir.

Sonuç: LiPA yöntemi ile sınırlı sayıda mutasyon incelenebildiği için, alınan ilaca karşı dirence neden olan farklı mutasyon paternlerinin saptanamayacağı, bu genleri saptamaya olanak veren sekanslama gibi ek bir yönteme başvurmanın faydalı olacağı kanaatine varımıştır. Ayrıca ilaç direnci nedeniyle meydana gelen tedavi başarısızlığı sonucunda, daha önce kullanılmamış yeni bir ilaç ile tedaviye devam edilecekse, bu antivirale karşı direnç oluşturan mutasyonların da bulunma intimalinin göz ardı edilmemesi gerektiği düşünülmüştür. Anahtar Kelimeler: Hepatit B, ilaç direnci, mutasyon

Saran B, Tüzüner U, Feyzioğlu B, Özdemir M, Baykan M. Determination of Resistance Mutation in Chronic Hepatitis B Patients Using Antiviral Drugs at Our Hospital. Viral Hepat J. 2017;23:30-33. 


\section{Introduction}

Although viral hepatitis B can be prevented via vaccination, it continues to be a threat for public health. 5-10\% of the adult population is chronically infected in sub-Saharan Africa and East Asia and an estimated 240 million people in the world are having chronic hepatitis B $(\mathrm{CHB})$. According to the data of the World Health Organization, cirrhosis or liver cancer develops in 20-30\% of chronically infected patients and more than 686.000 people die each year due hepatitis B complications such as liver insufficiency, cirrhosis and especially hepatocellular carcinoma. In our country, it is estimated that approximately 3-4 million people carries this virus. None of the treatment methods used can completely eradicate hepatitis $B$ virus (HBV) infection. Basis of all the treatments is to provide lifelong continuation of HBV suppression. The drugs used in HBV antiviral treatment consist of immuno-modulator agents (interferon and peginterferon) and oral antiviral agents (nucleotide and nucleoside analogues) $(1,2,3)$.

The use nucleotide/nucleoside analogues resulted in important problems such as mutation and drug resistance. In patients receiving drug treatment, it is known that mutations determined to be related to various drugs in viral polymerase genes are observed and they have caused in vitro reduction in drug sensitivity. Determination of these mutations in early period and prevention of unnecessary drug usage have a vital importance in terms of treatment success and it will also avoid toxicity caused by unnecessary drug usage and prevent unnecessary economic burden on the healthcare system.

In this study, it is aimed to determine the mutations causing antiviral resistance in patients with chronic HBV infection received/ receiving antiviral treatment and to evaluate the patients in terms of the treatment received and their HBV DNA levels.

\section{Materials and Methods}

We retrospectively evaluated the results obtained from 131 serum samples that were taken from patients diagnosed with $\mathrm{CHB}$ infection and were sent to the microbiology laboratory at Necmettin Erbakan University Meram Faculty of Medicine Hospital between January 2010 and January 2015 in order to determine drug resistance. Samples were studied with reverse hybridization principled INNO-LiPA HBV DR v2 (INNO-LiPA HBV DR; INNOGENETICS N.V., Ghent, Belgium) method. According to the manufacturer's recommendations, purified DNA samples were amplified by using primers. In the biotinylated PCR product, the presence of mutation was investigated via reverse hybridization method by using oligonucleotide probes specific to the mutation points on the nitrocellulose strips. Thirty two HBV probe lines showing wild type, mutant and mixed sequences for 80 th, $173^{\text {rd }}$, $180^{\text {th }} / 181^{\text {st }}, 204^{\text {th }}$ and $236^{\text {th }}$ polymerase codons were monitored colorimetrically and the bands formed were assessed by means of guide strips. HBV-DNA levels were examined simultaneously with the determination of mutation and during follow-up evaluation performed after 6-12 months by real-time PCR (COBAS TaqMan, Roche Diagnostics, France) method.

\section{Results}

Mutation was determined in 12 of 131 patients (9.1\%). While YMDD (Y: tyrosine, M: methionine, D: aspartate, D: aspartate) pattern change was determined on 204th codon in 10 patients, 7 of them were in the form of M204I tyrosine, isoleucine, aspartate, aspartate (YIDD) and 4 in the form of M204V tyrosine, valine, aspartate, aspartate (YVDD) and in one patient, it was observed to be multiple mutations as M204V+M204I+L180I. M204I mutation was seen singly in two samples, together with L80I mutation in two samples, with L180M mutation in one and with L80V mutation in one. L180M was determined in two and L180M+V/G173L mutation was determined in one of the samples with M204V mutation. Sole N236T and L80V mutation was determined in each patient sample. It was determined that the patient with YIDD resistance gene was receiving adefovir treatment and the patient with YVDD+L180M resistance gene was receiving entecavir treatment. It was specified that the patients with other resistance genes had received lamivudine treatment. No information was obtained regarding the treatment of the patients with $\mathrm{N} 236 \mathrm{~T}$ and YIDD+L80IN resistance profile. Observing HBV-DNA levels of the patients simultaneously with the determination of mutation and during follow-up evaluations performed after 6-12 months showed that DNA levels in 11 of 12 patients was decreased. An increase was observed in the DNA level in only one patient during the follow-up. Resistance profiles, drugs used and DNA levels of the patients are given in Table 1.

\section{Discussion}

$\mathrm{HBV}$ is a rapidly replicating virus. Mutation rate is high due to the absence of proofreading function of the reverse transcriptase enzyme in replication and it causes heterogeneous virus population in infected people. It is known that viral genome also generates adaptive mutations resulting in drug resistance formation especially under the suppression effect of the antiviral treatment. Antiviral drug resistance is also affected by the factors of host characteristics such as virusinfected hepatocyte, immune response, and genetic factors $(4,5)$.

Studies performed on various patient groups in our country revealed that there were various mutations reducing the drug

Table 1. Tyrosine, methionine, aspartate, aspartate patterns, received treatments and DNA levels of patients

\begin{tabular}{|l|l|l|}
\hline YMDD pattern changes & $\begin{array}{l}\text { Treatment } \\
\text { received }\end{array}$ & $\begin{array}{l}\text { DNA level follow-up } \\
\text { (copy/mL) (Initial } \\
\text { measurement - control } \\
\text { measurement) }\end{array}$ \\
\hline YVDD+YIDD+L80I & Lamivudine & $62060-0$ \\
\hline YIDD+L80I & - & $515620-0$ \\
\hline YVDD+L180M & Lamivudine & $6032-0$ \\
\hline YIDD & Lamivudine & $1210-0$ \\
\hline YVDD+L180M+V/G173L & Lamivudine & $>986 \times 10^{6}-28188$ \\
\hline YVDD+L180M & Entecavir & $638 \times 10^{6}-15 \times 10^{6}$ \\
\hline YIDD+L80I & Lamivudine & $887400-148$ \\
\hline YIDD & Adefovir & $>986 \times 10^{6}-28188$ \\
\hline YIDD+L180M & Lamivudine & $6612-2243$ \\
\hline YIDD+L80V & - & $174 \times 10^{6}-328 \times 10^{6}$ \\
\hline N236T & - & - \\
\hline L80V & Lamivudine & $1815400-<116$ \\
\hline $\begin{array}{l}\text { YMDD: Tyrosine, methionine, aspartate, aspartate, YVDD: Tyrosine, valine, } \\
\text { aspartate, aspartate, YIDD: Tyrosine, isoleucine, aspartate, aspartate }\end{array}$ \\
\hline
\end{tabular}


sensitivity at varying frequencies in untreated individuals or in inactive carriers and investigation of nucleotide and nucleoside analogues resistance mutations before the treatment was contentious in terms of price and efficiency $(6,7,8,9,10)$.

It has been shown that hybridization tests had high sensitivity and they could determine the mutations in some HBV populations which cannot be determined via sequences; their superiority over sequencing method in terms of interpretation, experience of personnel, conformance with the program used, time spent, and economic conditions have been revealed $(11,12,13)$.

It is known that the mutations occurred in the amino acid sequence in YMDD pattern in the gene area coding the HBV polymerase enzyme and expressed as rtM204V/l/S cause resistance development against lamivudine. In our study, among 10 patients with YMDD mutation, M204I (YIDD) was determined in 7 patients and M204V (YVDD) was determined in 4 patients. It has been shown that L180M/C mutation was almost present with YMDD mutations at all times and this has increased both replication and lamivudine resistance. It is noted that YIDD typemutations can be seen singly $(14,15,16,17)$. In a study by Akarsu et al. (8), it was noted that L180M accompanied by YMDD pattern change in 8 of 13 patients and YVDD pattern change was present in all cases having L180M mutation. In our study, it was observed that in 3 samples, YVDD and in one, YIDD mutations were accompanied by L180M mutation and no sole L180M mutation was found. In two patients, sole YIDD mutation was observed. In some studies, it has been shown that sole YVDD mutation could be seen and L180M mutation might accompany this mutation in the future and, in our study, no isolated YVDD mutation was observed $(8,14,18)$.

It has been shown that the lamuvidin resistance mutation rtM204IN together with rtT184G+rtS202I/C or rtM250V+rtl169T mutation is responsible for entekavir resistance $(16,19,20)$. In addition, it has been shown that adefovir resistance is related with rtN236T and/or rtA181TN mutation $(13,16,21,22)$. In our research, it was seen that a patient with YVDD+L180M mutation was receiving entecavir treatment and another patient with isolated YIDD mutation was receiving adefovir treatment. The possibility that these patients had previously received lamivudine treatment was also considered but no relevant data was obtained. Also it is suggested that there are other mutations causing entecavir and adefovir resistance, but since a limited number of mutations can be examined via LiPA method, these mutations could not be determined. Sequencing can be the method of choice to detect other mutations. Altındiş et al. (23) revealed compensatory mutations in treatment-naive $\mathrm{CHB}$ patients who have received both nucleoside/nucleotide analogues and lamivudine and/or adefovir treatments by sequencing method. rtQ149K, Q215S, Q215H, Q249K and V214A mutations were found to be associated with lamivudine and adefovir treatment; rtL91I mutation was found to be associated only with telbivudine and N238D with only adefovir.

Thus, in case of non-response to the treatment, using alternative methods for determining different potential mutations, such as sequencing, and revealing complex mutation patterns will be more useful for conducting the treatment. In addition, if there is a failure of treatment due to drug resistance and the treatment will be continued with a novel drug that has not been used before, the possibility of the presence of mutations causing a resistance against this antiviral should not be neglected.

It has been shown that rtL80V/I mutation was related with lamivudine resistance, $85 \%$ of the lamivudine-resistant isolates coded rtL80 and this mutation increased the replication skills of rtM204V/I mutants (24). In our study, rtL80V/I mutation was observed in a total of 5 patients; together with YMDD mutations in 4 patients and as isolated in one patient and, the rate of co-existence of YMDD mutations was found to be $50 \%$.

HBV DNA level follow-up is used as a significant parameter in monitoring the treatment efficiency. The presence of antiviral drug resistance genes mostly shows itself via viral load increase in patients receiving treatment. However, viral load is affected by the adherence of the patient to treatment and pharmacogenomic factors; it should be kept in mind that this parameter is not suitable to be used as a direct drug resistance indicator (4). In this study, DNA levels in patients with resistance gene were examined during the follow-up evaluation performed after 6-12 months. As a result of the resistance gene determination and the treatment plan that was rearranged afterwards, a decrease in HBV DNA levels was observed in 11 of 12 patients. An increase was observed in the DNA level in one patient during the follow-up. In this study, treatment follow-up was not monitored; it is considered that for patients with no decrease in DNA level, parameters such as qualification of the treatment regime change, presence of other possible mutations and the period of adherence to treatment should be investigated.

It has been shown that rtV173L mutation was seen in $9 \%$ of lamivudine-resistant cases and it has increased the replication capacity of lamivudine-resistant HBV and, anti-HBs binding capacity has decreased due to the change in the HBsAg structure of the virus with rtV173L+rtL180M+rtM204V triple mutation $(19,25,26)$. In our study, this triple mutation was determined in one patient (8.3\%) and the HBV DNA level in this patient was at the levels exceeding measurable upper limit of mutation (>986 copy/mL) and a decrease was observed during the follow-up evaluation performed after 6 months (28.188 copy/mL).

\section{Conclusion}

The samples sent to our laboratory for determination of resistance were retrospectively examined and mutation profiles, HBV DNA levels and the treatment received by the patients with resistance were evaluated. It was revealed that mutations have developed under antiviral treatment and this could be in the form of various drug resistance mutations. Further studies in which antiviral treatment periods are followed up for a longer term can demonstrate new and different information regarding mutation development. Early determination of the mutations causing drug resistance is required to provide opportunity to alternative treatment options and to provide a more efficient treatment.

\section{Ethics}

Ethics Committee Approval: A retrospective study, Informed Consent: A retrospective study.

Peer-review: Internally peer-reviewed. 


\section{Authorship Contributions}

Concept: M.B., Design: B.F., M.Ö., M.B., Data Collection or Processing: B.S., U.T., Analysis or Interpretation: B.S., B.F, M.Ö., M.B., Literature Search: B.S., U.T., B.F., Writing: B.S., U.T.

Conflict of Interest: No conflict of interest was declared by the authors.

Financial Disclosure: The authors declared that this study received no financial support.

\section{References}

1. Who: http://www.who.int/mediacentre/factsheets/fs204/en/.

2. Fung J, Lai CL, Seto WK, Yuen MF Nucleoside/nucleotide analogues in the treatment of chronic hepatitis B. J Antimicrob Chemother. 2011;66:2715-2725

3. Coşkun Ö, Savaş̧̧ı Ü, Eyigün CP. Current Treatment Strategies in Hepatitis B Virus Infections. Anatol J Clin Investig. 2012;6:299-310.

4. Zoulim F, Locarnini S. Hepatitis B Virus Resistance to Nucleos(t)ide Analogues. Gastroenterology. 2009;137:1593-1608.

5. Liu H, Mao R, Liu H, Mao R, Fan L, Xia J, Li Y, Yin Y, Li X, Zhao X Guo H, Zhu H, Zhang Y, Kang Y, Zhang J. Detection of lamivudineor adefovir-resistant hepatitis $B$ virüs mutations by a liquid array. $J$ Virol Methods. 2011;175:1-6.

6. Ergünay K, Kahramanoğlu Aksoy E, Şimşek H, Alp A, Şener B, Tatar G, Us D, Hasçelik G. Investigation of Baseline Antiviral Resistance in Treatment-Naive Chronic Hepatitis B Cases. Mikrobiyol Bul. 2013;47:628-635.

7. Yıldız $O$, Aygen B, Demirtürk N, Demirdal T, Inan D, Yıldırmak T, Kantürk A, Tütüncü E; Hepatitis B Study Group. Lamivudine resistance mutations in patients infected with hepatitis $B$ virüs genotype D. World J Gastroenterol. 2011;17:4987-4992.

8. Akarsu M, Sengonul A, Tankurt E, Sayiner AA, Topalak O, Akpinar $\mathrm{H}$, Abacioglu YH. YMDD motif variants in inactive hepatitis $B$ carriers detected by Inno-Lipa HBV DR assay. J Gastroenterol Hepatol. 2006;21:1783-1788.

9. Tunçbilek $S$, Köse $S$, Elaldi A, Akman S. Lamivudine resistance in untreated chronic hepatitis B patients in Turkey. Turk J Gastroenterol. 2008;19:99-103.

10. Sayan M, Akhan SC, Meric M. Naturally occurring amino-acid substitutions to nucleos(t)ide analogues in treatment naive Turkish patients with chronic hepatitis B. J Viral Hepat. 2010;17:23-27.

11. Niesters HG, De Man RA, Pas SD, Fries E, Osterhaus AD. Identification of a new variant in the YMDD motif of the hepatitis $B$ virus polymerase gene selected during lamivudine therapy. $J$ Med Microbiol. 2002;51:695-699.

12. Libbrecht E, Doutreloigne J, Van De Velde H, Yuen MF, Lai CL, Shapiro F, Sablon E. Evolution of Primary and Compensatory Lamivudine Resistance Mutations in Chronic Hepatitis B Virus-Infected Patients during Long-Term Lamivudine Treatment, Assessed by a Line Probe Assay. J Clin Microbiol. 2007;45:3935-3941.

13. Osiowy C, Villeneuve JP, Heathcote EJ, Giles E, Borlang J. Detection of rtN236T and rtA181V/T mutations associated with resistance to adefovir dipivoxil in samples from patients with chronic hepatitis B virus infection by the INNO-LiPA HBV DR line probe assay (version 2). J Clin Microbiol. 2006;44:1994-1997.
14. Aydoğan S, Ergünay K, Balaban $Y$, Alp A, Simşek H, Tatar G, Hasçelik G, Us D. Detection of Resistance Mutations in Chronic Hepatitis B Patients Receiving Antiviral Therapy for Over One Year. Mikrobiyol Bul. 2013;47:472-481.

15. Pai SB, Bozdayi AM, Pai RB, Beker T, Sarioglu M, Turkyilmaz AR, Grier J, Yurdaydin C, Schinazi RF. Emergence of a novel mutation in the FLLA region of hepatitis $B$ virus during lamivudine therapy. Antimicrob Agents Chemother. 2005;49:2618-2624.

16. Sayan M, Akhan SC, Senturk O. Frequency and mutation patterns of resistance in patients with chronic hepatitis B infection treated with nucleos(t)ide analogs in add-on and switch strategies. Hepat Mon. 2011;11:835-842.

17. Tan YW, Ge GH, Zhao W, Gan JH, Zhao Y, Niu ZL, Zhang DJ, Chen $L$, Yu XJ, Yang LJ. YMDD motif mutations in chronic hepatitis $B$ antiviral treatment naïve patients: a multi-center study. Braz $J$ Infect Dis. 2012;16:250-255.

18. Arslan U, Ural O, Findık D. YMDD motif variants detected by Inno-Lipa HBV DR assay in chronic hepatitis b patients during lamivudine therapy. Mikrobiyol Bul. 2008;42:445-450.

19. Bartholomeusz A, Locarnini SA. Antiviral drug resistance: clinical consequences and molecular aspects. Semin Liver Dis. 2006;26:162-170

20. Tenney DJ, Levine SM, Rose RE, Walsh AW, Weinheimer SP, Discotto L, Plym M, Pokornowski K, Yu CF, Angus P, Ayres A, Bartholomeusz A, Sievert W, Thompson G, Warner N, Locarnini $\mathrm{S}$, Colonno RJ. Clinical emergence of entecavir-resistant hepatitis $B$ virüs requires additional substitutions in virus already resistant to Lamivudine. Antimicrob Agents Chemother. 2004;48:34983507.

21. Shaw T, Bartholomeusz A, Locarnini S. HBV drug resistance: mechanisms, detection and interpretation. J Hepatol. 2006;44:593606.

22. Angus $P$, Vaughan $R$, Xiong $S$, Yang $H$, Delaney $W$, Gibbs $C$, Brosgart C, Colledge D, Edwards R, Ayres A, Bartholomeusz A, Locarnini S. Resistance to adefovir dipivoxil therapy associated with the selection of a novel mutation in the HBV polymerase. Gastroenterology. 2003;125:292-297.

23. Altındiş $\mathrm{M}$, Aslan FG, Koroğlu M, Eren A, Demir L, Uslan MI, Aslan S, Özdemir M, Baykan M. Hepatitis B Virus Carrying Drug-resistance Compensatory Mutations in Chronically Infected Treatment-naive Patients. Viral Hepat J. 2016;22:103107.

24. Warner N, Locarnini S, Kuiper M, Bartholomeusz A, Ayres A, Yuen L, Shaw T. The L80I substitution in the reverse transcriptase domain of the hepatitis B virus polymerase is associated with lamivudine resistance and enhanced viral replication in vitro. Antimicrob Agents Chemother. 2007;51:2285-2292.

25. Delaney WE, Yang H, Westland CE, Das K, Arnold E, Gibbs CS, Miller MD,Xiong S. The hepatitis B virus polymerase mutation rtV173L is selected during lamivudine therapy and enhances viral replication in vitro. J Virol. 2003;77:11833-11841.

26. Torresi J. The virological and clinical significance of mutations in the overlapping envelope and polymerase genes of hepatitis $B$ virus. J Clin Virol. 2002;25:97-106. 